\title{
An Empirical Study on the Allocation Structure of Human Capital Elements and Company Performances --Based on the Experiences and Evidence of the High-tech Companies in Chang- chun High-New Tech Development Zone
}

\author{
Song YunYan ${ }^{1}$ YuJun $^{2}$ \\ ${ }^{1}$ Accounting Department Jilin Business and Technology College Changchun, China \\ songyunyan08@163.com.cn \\ ${ }^{2}$ Accounting Department Jilin Business and Technology College Changchun, China \\ yujun@jlbtc.edu.cn
}

\begin{abstract}
Human capital element consists of education and knowledge capital, professional skill capital and working experience capital. The allocation structure of human capital element refers to the component proportion of different levels of the same human capital element. Based on the empirical study, we find that the allocation of three elements of human capital has a strong influence on the company's performance. Therefore, the paper raises the standard of education status for employee hiring. It also offers the suggestions of improving the employees' organizing/ learning capability and bringing "working age" into Motivation System to optimize the human capital elements allocation structure.
\end{abstract}

Keywords: Human capital element,allocation structure, company performance, empirical study

\section{RAISING QUESTION}

Structure refers to the proportion of some thing's constitution of different layers, which belong to the same or different classification. Capital structure refers to the consisting proportion of different capital elements. In the time of knowledge economy, capital consists of material capital and human capital. Traditional capital structure is the material capital structure. That is the proportion of equity capital and debt capital. The theory of capital structure, which is formed in $1950 \mathrm{~s}$, focuses on the research of relation between the material capital structure and the value of company. MM theory, trade-off theory, agency theory and pecking order theory are some classic ones in the area of material capital structure study, but they pay no attention to human capital, human capital structure and their relation with the value of company.

In the half past century, the material capital structure theory has making a lot of breakthroughs. The relationship between material capital structure and value 
of company becomes clearer and clearer. For example, the revised MM theory concerning income tax believes the value of company will be increased with the increasing effects of leverage, trade-off theory, which is based on MM theory, talks about too much debt of the company will cause the financial distress and financial distress cost, agency theory, which evaluates the cost of liability agency and the benefits of agency, believes the agency cost and benefits caused by company liabilities will give influence to the value of the company. All these theory proved the changes of capital structure will definitely cause the changes of the value of company. Therefore, there must be a capital structure to maximize the value of company----the optimal capital structure. The object of capital structure management is to reasonably determine the capital structure and maximize the value of company.

We have known the change of material capital structure will influence the value of company. Then what about the change of human capital structure? If it is true that the change of human capital structure will influence the value of company, how does the company allocate human capital and maximize its value? This paper, based on the theory analysis and the statistics of the survey of the companies in Changchun High/New Tech development Zone, proves the changes of human capital elements allocation will influence the company performance. Furthermore, the author offers some suggestions to upgrade human capital elements allocation..

\section{2. theory analysis and research hy- pothesis}

Before the research of the relation between human capital structure and the value of company, we must make clear the connotation and consisting elements of human capital. In 1960, the American famous economist, Theodore W. Schultz gave a speech on the Human capital Investment in America economy annual conference. This is the symbol of the birth of modern human capital theory. Theodore believes human capital exists in the laborers, takes the form of investment, and consists of the laborers' knowledge, skills, capabilities and physical power. ${ }^{[1]}$ Famous American economist Gary.S.Becker (1989) makes a further step. He points out human capital doesn't only refer to talent, knowledge and skill, but also means time, health and life. ${ }^{[2]}$ Anner Booing (1996) defines human capital as a whole of employees' skill, creativity, problem solving ability, leadership talent, enterprising spirit and management capability. ${ }^{[3]}$ Edvinsson\&Malone (1997) believe human capability is a combination of employee's various skills, knowledge and creativity, is the source of intellectual capital creation. It exists in a potential and non-coded form and belongs to the employees. ${ }^{[4]}$ It is obvious that the foreign scholars define the connotation of human capital by listing all or part of the components of human capital. Therefore, the definition of human capital has revealed the components of human capital. Chinese scholars borrow the definition of human capital from foreign scholars'. Li Shibai (2002) regards human capital as the laborer's knowledge, skill and the capabilities they show up. It is created by the investing to human, and showed up through human's high degree of intelligence and skill. ${ }^{[5]}$ Zhang Wenxian and Fu Xin (2006) divides the human capital into intellectual capital, relation capital and structure capital according to the connotation of human capital. Some of Chinese scholars divide human capital according to human's ability. Li Zhongmin, based on the observational phenomena, classifies human ability into four types. They are average ability, the ability of accomplishing specific work, 
organizing and managing ability and resource allocating ability. Accordingly, there are four standard human capital---average human capital, skill-based human capital, management-based human capital and entrepreneur typed human capital. Wang Junfeng and Hu Yali (2007) classify the human capital into production typed human capital, skill-based human capital, management-based human capital and recourse-based (entrepreneur typed) human capital. Some scholars give the classification according to human capital's effects and effect degree. Yao Ligen and Han Baitang (2007) classify human capital into nuclear human capital, specialized human capital, assisting human capital and essential human capital according to its effect. Xiang Xianhu (2006) classifies human capital into high-level, average-level and basic-level human capital according to its different degrees of effect. It is clear that there is no unified understanding of human capital component. That is because the scholars give different concept on different research purposes. Based on the above ideas, we define human capital as the combination of employee's knowledge, skill and experience. In this paper, human capital is divided into education and knowledge capital, professional skill capital and working experience capital.

\subsection{Education and Knowledge Capi- tal and Company Performance}

Education and knowledge capital refers to the human capital acquired through the formal schooling. It is the basement of human capital structure and the knowledge foundation of other human capital elements. Knowledge is a kind of inside value labor product, and can be transferred into actual value. The use of knowledge can produce new values which are bigger than the costs on buying and producing them. (Zhang Zhi 1998 ) Education and knowledge capital can be put into production directly, help the forming and upgrading of other human capital elements, and raise the efficiency of the investment of other human capital elements. Without good education, workers are hard to master the working skills, without knowledge, enterprises are hard to produce added values. Peter Drucker, in his Post Capitalist Society, points out knowledge will replace machine, money, material and laborer and become the most important production factor . Nonaka (1994) gives four models of knowledge transfer, develops these models into knowledge transfer program, and promotes the personal knowledge to a higher level that is to create new knowledge. Education and knowledge capital is a dynamic one. In ever changing market, it can be accumulated, deposited, disintegrated to create new knowledge and skills, and can produce values for companies persistently. Education and knowledge capital index can be reflected by employee's education status. We classify the employee's education status into high, middle and low level according to their education length. Hypothesis 1: the higher workers' education status is, the better company performance becomes.

\subsection{Professional Skill Capital and Company Performance}

Professional skill refers to employee's capability to create values by using knowledge and skills in professional work. It is the knowledge carrier. Professional skill capital is a kind of the human capital which is acquired through professional education and can be applied into production and service directly. It is the centre of human capital and the ultimate object of human capital investment. Human capital investment aims to form the good professional skill capital, to push the product innovation, to improve productivity and to promote economic growth. Professional skill capital index 
can be reflected by employee's professional level. We classify the employee's professional level into high, middle and low level. Different level has different limit accrual. Hypothesis 2: the higher workers' professional skill levels are, the better company performance becomes.

\subsection{Working Experience Capital and Company Performance}

Experience is the knowledge and skill acquired through long time practice. Working experience capital is a standard "learning in doing" human capital, which is resulted in recourse input and energy accumulation. Experience accumulation is also a process of learning and exploring. In working, employees can accumulate methods and skills with the help of their colleagues and clients. The rich and practical experience will definitely improve the efficiency, performance and value of the company. Working experience capital index can be reflected by employee's working years. Working experience is increased with the increasing working years. Hypothesis 3: the more workers' working years are, the better company performance becomes.

\section{3. variable, sample and research re- sult}

\subsection{The Definition of Variable}

\section{Explained Variable}

Rate of Return on Common Stockholders Equity (ROE) are worked as explained variable in this paper

Explanatory Variable

The structure of education and knowledge capital is reflected by the proportion of the employees' different education status. The structure includes master or higher degrees, bachelor or higher degrees and college or higher degrees. The professional skill capital is reflected by the proportion of the employees' dif- ferent professional skill levels. It also has three levels: advanced or above technical title (A-level) and middle rank or above technical title (M-level), and primary or above technical title The working experience capital is reflected by the proportion of the employees' different working years. It includes 10 working years or more, 3 working years or more and 1 working year or more.

Controlled Variable

Since the size of the company and financial leverage can influence the company performance, we choose the natural logarithm of the total capital and assetliability ratio to represent size of the company (size) and financial leverage (lev) and to play the role of controlled variables.

\subsection{Sample Statistics}

The research statistics come from the questionnaires collected from 116 hightech companies in Changchun High/New Tech development Zone, among which 42 are valid and complete (valid recovery rate: $36.2 \%$ ). Most of the 42 companies are Technological Small and Mediumsized Enterprises. Their registered type is non-state-owned limited liability company. The 42 companies are very typical. 6 of them are electronic information companies, 5 are biological medicine companies, 2 are new material companies, 7 are optical and electronic integration companies, 6 are new resources companies, 2 are environment protection companies, 7 are software companies, others are 7

\subsection{Descriptive Statistics}

A Chart 1 gives the report of variables descriptive statistics. The average ROE is $9.8 \%$, and the standard deviation is 10.95 . This means the companies vary a lot in their performance. The proportion of the employee having a master or higher degrees is $1.5 \%$, and having bachelor or higher degrees is $19 \%$. This number is not high for high-tech companies. The 
proportion of the employee having an advanced technical title is $2.2 \%$, and middle level technical title occupies $14.6 \%$. The professional skill title of the employees in the sample companies is not high. That is probably because in small and mediumsized enterprises, especially the private ones, the enterprises care more about the employees' practical skill and ability than the rating of technical titles. The proportion of the employees having 10 or more working years is $14.28 \%$, and having 3 or more working years occupies $41.12 \%$.

- TABLEI. descriptive statistics of variables

\begin{tabular}{|c|c|c|c|c|c|}
\hline Variable & Average & $\begin{array}{c}\text { Standard } \\
\text { Deviation }\end{array}$ & Variable & Average & $\begin{array}{c}\text { Standard } \\
\text { Deviation }\end{array}$ \\
\hline ROE & 0.098412 & 0.109511 & P-level & 0.287612 & 0.115915 \\
\hline Master & 0.015145 & 0.023516 & 10years & 0.142804 & 0.106845 \\
\hline Bachelor & 0.191623 & 0.088517 & 3years & 0.411158 & 0.188723 \\
\hline College & 0.577013 & 0.174112 & lyears & 0.967347 & 0.046656 \\
\hline I-level & 0.022125 & 0.111653 & Size & 16.64445 & 1.059423 \\
\hline S-level & 0.145847 & 0.096805 & Lev & 0.123528 & 0.148026 \\
\hline
\end{tabular}

This explains the employees' working years in sample companies are less because of the short time of the companies' establishment. We need note that the sample companies' average asset-liability ratio is only $12.36 \%$, which means it is still hard to finance for small and medium-sized enterprises

\subsection{Regression Result Analysis}

All the models have a high degree of goodness of fit, D.W statistic is nearly 2, the average $\mathrm{F}$ is $1 \%$, which is clearly different from 0 . Therefore the models are tenable. In all the models, the size and the performance of the company have negative correlation, but it is not obvious. The financial leverage and company performance have positive correlation, which means the increased assets liability rate can lead to better company performance.

Chart 2 reports the results of education and knowledge capital and company performance analysis. It is clear that different education and knowledge capital structures influence the company performance strongly. Among these structures, the employees who have a master or higher degrees devote more to company performance. The first hypothesis is proved. Chat 3 gives the result of professional skill capital and company performance analysis. The employees, who have middle-level and above technical titles and primary and above technical titles, have positive correlation with the company performance. They make a great devotion to the companies. The employees who have advanced and above technical titles also have positive correlation with company performance, but their influences are not remarkable. Hypothesis 2 can not be completely proved. We can conclude the best way to allocate professional skill capital is to reasonably adjust the proportion of employees who have primary and middle-level technical titles instead of simply improving the proportion of advanced technical title. Though people have advanced technical title create more value, their costs are also higher. This might be the reason why their influences to company performance are not distinctive. Chart 4 reports the research result of working experience capital and company performance analysis.

- TABLE II. education and knowledge capital and company performance

\begin{tabular}{|c|c|c|c|c|c|c|}
\hline \multirow{2}{*}{ Variable } & \multicolumn{2}{|c|}{ Model 1 } & \multicolumn{2}{c|}{ Model 2 } & \multicolumn{2}{c|}{ Model 3 } \\
\cline { 2 - 7 } & Coef. & Prob. & Coef. & Prob. & Coef. & Prob. \\
\hline C & 0.23123 & 0.2719 & 0.03986 & 0.0219 & -0.1763 & 0.291 \\
\hline Master & 1.58454 & 0.0518 & & & & \\
\hline Bachelor & & & 0.38278 & 0 & & \\
\hline College & & & & & 0.40116 & 0 \\
\hline Size & -0.01126 & 0.3626 & -0.00859 & 0.1028 & -0.00401 & 0.1627 \\
\hline Lev & 0.27917 & 0.0359 & 0.12818 & 0.0103 & 0.2438 & 0.002 \\
\hline Adj-R ${ }^{2}$ & 0.799827 & 0.792549 & 0.883902 \\
\hline F-statistic & 10.10516 & 20.87627 & 30.56846 \\
\hline D.W stat & 1.723023 & 1.672538 & 2.117918 \\
\hline
\end{tabular}

The proportion of 10 and above and 3 and above working experience has positive correlation with company performance. The proportion of 1 and above working years has negative correlation with company performance, but the negative correlation is not striking. Hypothesis 3 is proved 
- TABLE III. professional skill capital and company performance

\begin{tabular}{|c|c|c|c|c|c|c|}
\hline \multirow{2}{*}{ Variable } & \multicolumn{2}{|c|}{ Model 4 } & \multicolumn{2}{c|}{ Model 5 } & \multicolumn{2}{c|}{ Model 6 } \\
\cline { 2 - 7 } & Coef. & Prob. & Coef. & Prob. & Coef. & Prob. \\
\hline C & 0.24118 & 0.2687 & 0.04187 & 0.7973 & 0.05438 & 0.7219 \\
\hline I-level & 0.14459 & 0.2517 & & & & \\
\hline S-leve1 & & & 0.3542 & 0 & & \\
\hline P-leve1 & & & & & 0.3421 & 0 \\
\hline Size & -0.0126 & 0.3403 & -0.0024 & 0.5701 & -0.0059 & 0.3335 \\
\hline Lev & 0.4789 & 0 & 0.2068 & 0.0125 & 0.1927 & 0.0148 \\
\hline Adj-R & 0.861969 & 0.851645 & 0.791183 \\
\hline F-statistic & 8.753558 & 26.56705 & 31.58919 \\
\hline D.W stat & 1.755115 & \multicolumn{2}{|c|}{1.891357} & \multicolumn{2}{c|}{1.774511} \\
\hline
\end{tabular}

- TABLE IV. working experience capital and company performance

\begin{tabular}{|c|c|c|c|c|c|c|}
\hline \multirow{2}{*}{ Variable } & \multicolumn{2}{|c|}{ Model 7 } & \multicolumn{2}{c|}{ Model 8 } & \multicolumn{2}{c|}{ Model 9 } \\
\cline { 2 - 7 } & Coef. & Prob. & Coef. & Prob. & Coef. & Prob. \\
\hline C & 0.20618 & 0.3357 & 0.08446 & 0.6873 & 0.33557 & 0.3835 \\
\hline 10years & 0.18567 & 0.0971 & & & & \\
\hline 3ears & & & 0.24433 & 0.0112 & & \\
\hline lyears & & & & & -0.0924 & 0.7576 \\
\hline Size & -0.0112 & 0.369 & -0.0071 & 0.5668 & -0.0121 & 0.3647 \\
\hline Lev & 0.31738 & 0.0142 & 0.2483 & 0.0385 & 0.45657 & 0 \\
\hline Adj-R ${ }^{2}$ & 0.885914 & 0.843525 & 0.840968 \\
\hline F-statistic & 9.588811 & 11.89358 & 8.070865 \\
\hline D.W stat & 1.804228 & 1.713714 & 1.726816 \\
\hline
\end{tabular}

\section{CONCLUSION AND SUGGES- TION}

The research proves the allocation of human capital elements has significant effect on the company performance. Accordingly, we raise the following suggestions: first, the education status should be the important criterion for recruitment. The employees should have the college education background at least. Second, try to improve the organizing and learning abilities. Organizing and learning ability is a kind of capability which helps you learn faster and create the future yourself (Xu Guoxue 2005). Learning is a process of mastering skill and knowledge, and also a process of creating skill and knowledge. Therefore organizing and learning can generate professional skill capital, can cultivate and develop talents, and reflect the good allocation of enterprise techniques. At the same time, we should pay attention of the employees', especially the common employees' train- ing to help them reach the primary and middle level of professional skills and perfect the professional skill capital structure. Third, in the management of human resource, the company should encourage long time service of employees, avoid their "job-hopping", introduce "working age" into motivation system and rational allocate working experience capital structure. Four, the company should improve the modern enterprise management, create good conditions, enhance the financing ability, promote the company performance.

\section{Acknowledgment}

This is initial resultsof Foundation project: The Education Department of Jilin province social science research projects:" Intellectual capital financial control theory and method research"

\section{References}

[1] Theodore.W.Schults, "Human Capital Investment----Education and Research Function" , [M].Commercial Press , Beijing, 1990.

[2] Gary.S.Becke, "Human Capital", $[\mathrm{M}]$, Beijing University Press, Beijing r, 1989.

[3] Annie Brooking , "Intellectual Capital" , [M]' . Thomson Learning, 1996.

[4] Edvisson L . and Malone M.S., "Intellectual Capital" [M] . Harper Busmess, New York, 1997.

[5] Li Shibai, "the Choice for Improving Human Capital in Western China", $[\mathrm{J}]$, Journal of Shangxi University of Finance and Economics, 2002.

[6] Zhang Wenxian, Fu Xin, "Human Capital Centered Capital Structure", [J], Economist, 2006.

[7] Li Zhongmin, "Human Capital",[M] , Economics and Science Press , Beijng, 1999.

[8] Wang Junfeng, $\mathrm{Hu}$ Yali, "Human Capital Influence to Enterprise Capital Structure",[J],Commercial Age,2007. 